\title{
Erratum to: selection of suitable passive cooling strategy for a subtropical climate
}

\author{
Shams Forruque Ahmed ${ }^{1 *}$, Mohammad Masud Kamal Khan ${ }^{1}$, Amanullah Maung Than Oo 1,2 \\ and Mohammad Golam Rasul ${ }^{1}$
}

\section{Erratum}

In the original version of this article (Ahmed et al. 2014), the authors noted that the author list was published with errors. The correct author list can be found in this erratum. The publisher would like to apologise to the authors for this error.

\section{Author details \\ 'School of Engineering and Technology, Central Queensland University, Rockhampton Campus, Queensland 4702, Australia. ${ }^{2}$ School of Engineering, Deakin University, Geelong Waurn Ponds, Victoria 3216, Australia.}

Received: 29 March 2015 Accepted: 29 March 2015

Published online: 29 April 2015

\section{Reference}

Ahmed, SF, Khan, MMK, Ammanullah, MTO, Rasul, MG (2014). Selection of suitable passive cooling strategy for a subtropical climate. International Journal of Mechanical and Materials Engineering, 9, 14.

\footnotetext{
* Correspondence: s.f.ahmed@cqu.edu.au

'School of Engineering and Technology, Central Queensland University, Rockhampton Campus, Queensland 4702, Australia

Full list of author information is available at the end of the article
}

Submit your manuscript to a SpringerOpen ${ }^{\circ}$ journal and benefit from:

- Convenient online submission

- Rigorous peer review

- Immediate publication on acceptance

- Open access: articles freely available online

- High visibility within the field

- Retaining the copyright to your article

Submit your next manuscript at $>$ springeropen.com 